\title{
A Conceptual Framework of Strategy Cascading in the Mission-Based Organizations: A State-of-the-Art Review and Practical Template
}

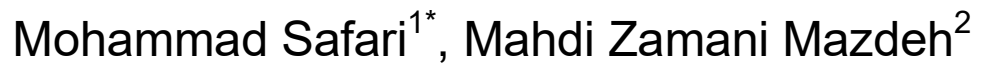 \\ ${ }^{1}$ Faculty of Management, University of Tehran, Tehran, Iran \\ ${ }^{2}$ Department of MBA, Payam Noor University, Iran \\ *E.Mail: m.safari@ut.ac.ir
}

Keywords: strategic management, organization, cascading, mission, vision, strategy, operational program.

\begin{abstract}
What matters in strategic management for the organization and can move the organization forward, is translating the strategies developed in the strategic planning phase into the operational program in the implementation phase. In other words, cascading the strategic plan into a form of an operational program is a key to organizational success. Strategic success will be achieved if the right strategies are cascaded in the organization rightly. The purpose of this research is to provide a framework for the strategic plan cascading into steps and an operational process to facilitate its implementation in the organization. For this purpose, the mission-focused organizations were considered. These organizations go beyond profitability and following the implementation of strategies and action plans are in searching to fulfill the mission for which it is designed and developed. Here, the ultimate goal is to achieve a designated and defined mission. This qualitative analytic research is seeking to provide a framework for cascading organizational strategies using a scientific and applied approach. After presenting the research's conceptual framework, in order to test and analysis the model, using experts' viewpoints through a questionnaire required data was gathered and analyzed. The results and findings of this research show that for the implementation of the developed strategies, a systematic and stepwise model is needed that consists of several stages: the formulation of strategies, the prioritization of strategies with strategic tools, comparative studies to find the transformation of the strategy into the program, and finally the design of the operational program and its quantitative objectives and measures.
\end{abstract}

\section{Introduction}

With the onset of the over-industrial period, the organization's environment has become dynamic and complex, and complexity has emerged as a dominant issue in organizations. Today, the most important concern of most organizations is to formulate and implement strategies that ensure their success and survival in a complex environment. To preserve the survival and success of organizations in a mysterious and competitive environment of the contemporary world which changes, speed, complexity and uncertainty are the main characteristics of it, it requires the selection and implementation of strategies and consequently effective and continuous improvement [9]. Strategic planning provides organizations with the tools to pursue strategy development and implementation in different aspects of the organization and manage their strategic performance [12], [16]. Strategic management is a prospective, long-term, integrated, transformative management based on the recognition of the environment and its changes. After managing the process, the management draws up a specific strategy that, with its implementation and monitoring, makes it possible to achieve the mission of the organization in the best possible way [24]. Both theoreticalscientific studies and empirical findings from different organizations have shown that strategy implementation is the most important stage in strategic management and will bring outstanding achievements for the organizations. Hence, what is important in strategic management processes is that strategic plans are translated into operational plans and facilitated by their implementation in the organization. The main responsibility for the effective implementation of strategies is related to the top management of the organization. The implementation stage of the strategy is far more difficult 
than designing a strategy plan because it needs to translate strategy ideas and orientations into action. Implementation of strategic plans is based on participatory development, executive commitment of managers, organizational environment and internal factors. Participatory formulation (human resources participation in compilation, motivation for participation, formation of committees' leadership, Skilled formulator) is a prerequisite for the creation of a managerial commitment [15]. The main research question of this study is as what the appropriate framework or detailed model is to execute and implement the strategic plans of the mission-based organization? Consequently, and therefore, the main problem of this study is to provide a framework for implementing strategic plans for mission-based organizations. This will be done through a detailed review of previous research works and then interviews with field's experts.

\section{Strategic Management}

The concept of strategic management appears in the years 1950-60, with the works of the renown's authors like Alfred D. Chandler, Philip Selznick, Igor Ansoff and Peter Drucker [18]. The global economic landscape and business world are changing rapidly. Strategic management in turbulent conditions needs to be pro-active. Just when managers think they have developed a strategy for future success, a new technology, process, competitor or customer behavioral pattern emerges [23]. Regarding the features of the strategic management topic, its multi-dimensionality, and its large extent, several definitions are mentioned. One of the most famous experts and scholars in the field of strategic management has provided a comprehensive definition of strategic management that is the basis of many scientific researches around the world, which is that: Strategic management can be defined as the art and science of formulating, implementing, and evaluating cross-functional decisions that enable an organization to achieve its objectives. As this definition implies, strategic management focuses on integrating management, marketing, finance/accounting, production/operations, research and development, and information systems to achieve organizational success [6]. Strategic management is a domain that is used by many organizations and companies in various industries. For example, research results published over the past two years show different countries and organizations. The scholars and researchers made insights for the better work on the strategy management and execution. Mondragon et (2017) presented a strategic planning model for the passenger rail implementation process in Mexico. Liu and de Bont [14] provided the 12 main barriers to the adoption of strategic design in Chinese corporations. Dmitrieva et al. [7] reviews research of strategic management and using Strategic management tools analyzed the environment of the of the potash industry in Russia subsequently and finally made insight for the research. Pröllochs and Feuerriegel [21] identified and provided business analytics for strategic management and perform a novel research in this field of study.

Also, other scholars proposed definitions. Strategic management is the formulation and implementation of the major goals and initiatives taken by a company's top management on behalf of owners, based on consideration of resources and an assessment of the internal and external environments in which the organization competes [19]. Alfred D. Chandler, author of Strategy and Structure [26], the classic study of the relationship between an organization's structure and its strategy, defined strategy as "the determination of the basic long-term goals and objectives of an enterprise, and the adoption of courses of action and the allocation of resources for carrying out these goals." [20]. Ghemawat [8] states that strategic management provides overall direction to the enterprise and involves specifying the organization's objectives, developing policies and plans designed to achieve these objectives, and then allocating resources to implement the plans. Academics and practicing managers have developed numerous models and frameworks to assist in strategic decision making in the context of complex environments and competitive dynamics [8].

In general, the various stages of strategic management have been identified and suggested by the experts. Strategic management requires an assessment of a firm's internal and external environments [21]. The most basic model proposed in this context is to separate it into several successive stages. These steps are including environmental scanning, strategy formulation, strategy 
implementation and execution and strategy evaluation and control. Fig. 1 shows this basic model for better understanding.

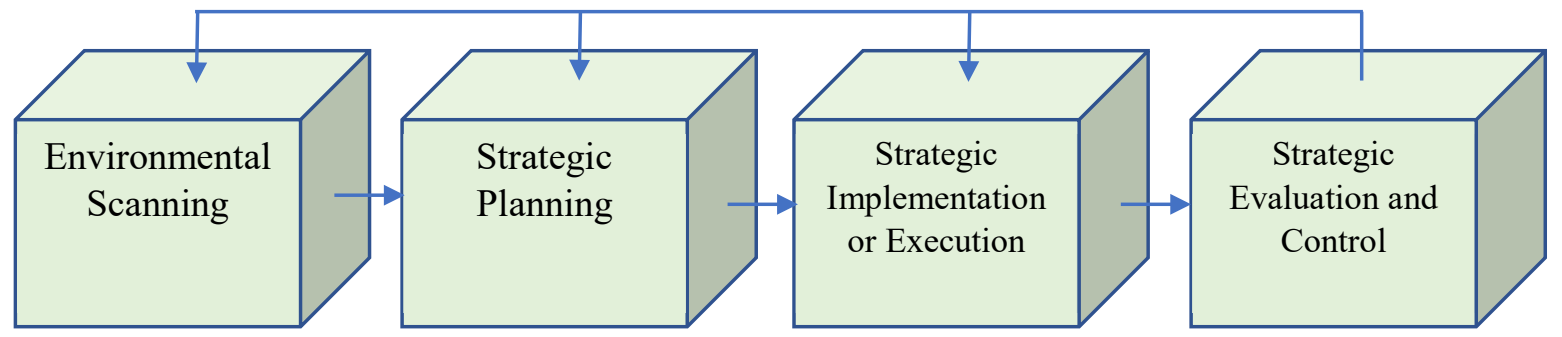

Figure 1. Basic stepwise model of strategic management

Also, based on the overall and basic model of strategic management, detailed and comprehensive model of strategic management which has been identified and presented by Fred R. David Can provide an appropriate and analytical framework for audiences in recognizing strategic management and related activities. Fig. 2 shows in detail the comprehensive model of strategic management for organizations. This model has been used and applied in many companies and organizations in past decades all around the world.

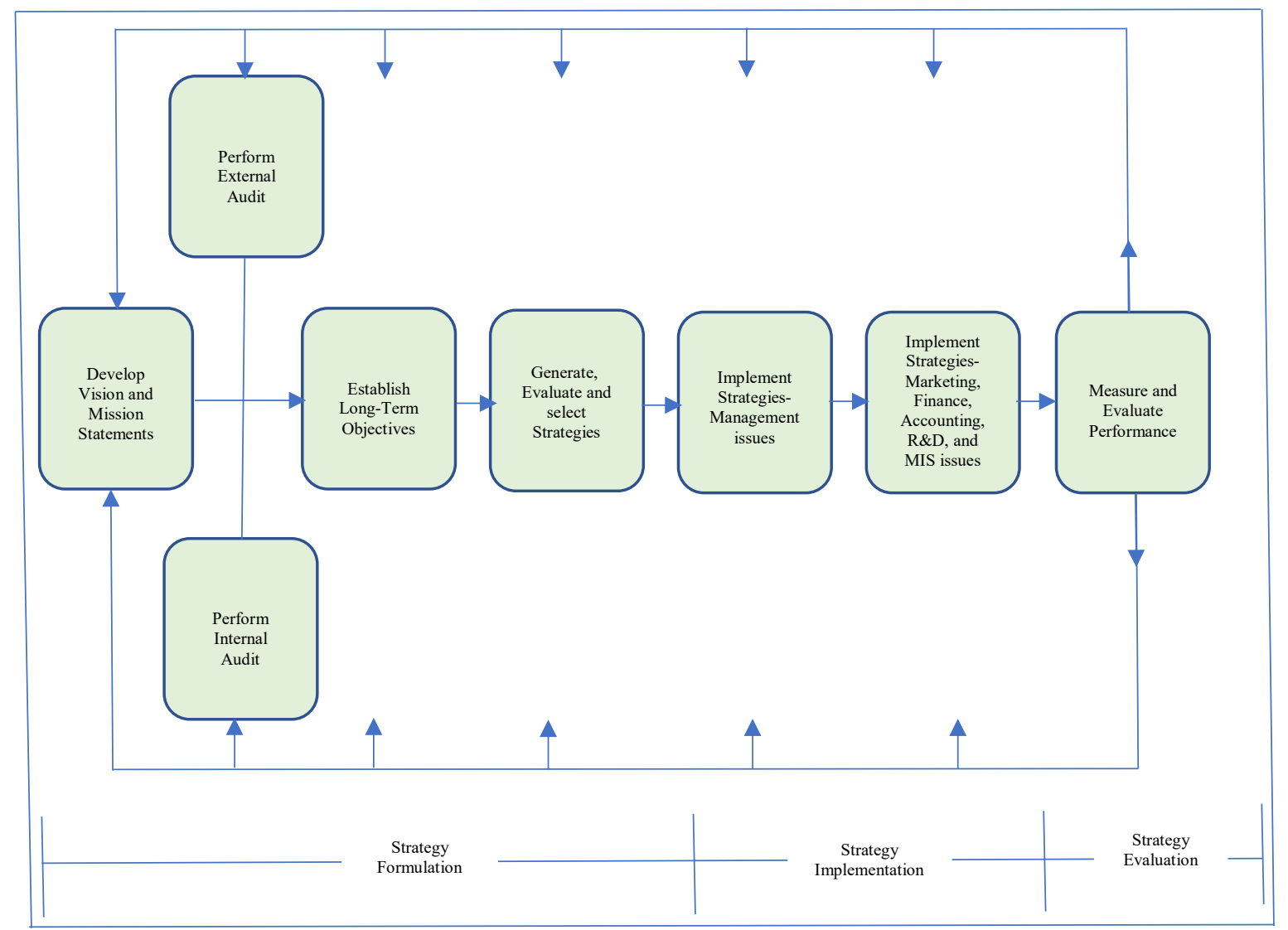

Figure 2. The comprehensive strategic management model [6]

In order to develop a strategy framework have been identified. A Comprehensive Framework for Strategy Formulation is shown in Fig. 3. This framework starts with "Determine the mission and prepare a statement of the mission of the organization" and will terminated with "Formation and implementation of Quantitative Strategic Planning Matrix" [6], [3], [2]. 
Table 1. Framework and strategy development tools

\begin{tabular}{|l|l|}
\hline \multirow{2}{*}{ Start step } & $\begin{array}{l}\text { Determine the mission and prepare a statement of the mission } \\
\text { of the organization }\end{array}$ \\
\hline \multirow{2}{*}{ Input step } & External Factors Assessment Matrix \\
\cline { 2 - 2 } Comparison step & Internal Factors Assessment Matrix \\
\hline \multirow{2}{*}{ Decision making step } & Combination of internal and external matrix \\
\cline { 2 - 2 } & QWOantitative Strategic Planning Matrix \\
\hline
\end{tabular}

\section{Strategic Execution}

Over the past two decades, strategy formulation has been recognized as the most important component of strategic management, but recent research has shown that strategy implementation is more important than strategy formulation, and the key to the performance of superior companies is to perform better [10], [11]. So that experts believe that if big strategies cannot be implemented, they are worthless [22], [25]. Unlike many managers' perception, the success of the premier organizations isn't depending on having a good strategy but related to a good implementation of a strategy. Today, implementation of strategy is believed to be a dynamic process in strategic management. Understanding people about strategy implementation is not clearly as strategic formation. indeed, in strategic management literature, implementation of strategy is different from that of formation. Indeed, what brings competitive advantage to the organization is a complete and superior implementation of the strategy.

Organizations often fail at strategy execution. Various sources have reported implementation failure rates at between 60 and 90 percent [13]. Using some form of dashboard to chronicle and explore progress in implementation is a natural and essential step in the implementation of any strategic plan [1]. Different research has identified and presented several factors for implementing the strategy. Table 2 illustrates the division of the variables involved in the implementation of the strategic plan.

Table 2. Categorization of the variables to strategy execution [15]

\begin{tabular}{|c|c|c|c|c|c|}
\hline \multicolumn{4}{|c|}{ Structural issues } & \multirow{5}{*}{$\begin{array}{l}\overrightarrow{\mathrm{x}} \\
\stackrel{0}{0} \\
\text { U }\end{array}$} & \\
\hline $\begin{array}{l}\text { Belief, } \\
\text { motivation } \\
\text { and } \\
\text { perception }\end{array}$ & Individual & \multirow{3}{*}{ Behavioral } & \multirow{4}{*}{$\begin{array}{l}\text { Human } \\
\text { problems }\end{array}$} & & 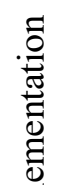 \\
\hline $\begin{array}{l}\text { Leadership, } \\
\text { conflict }\end{array}$ & Group & & & & $\vec{\Xi}$ \\
\hline $\begin{array}{c}\text { Culture, } \\
\text { organizational } \\
\text { climate and } \\
\text { change }\end{array}$ & Organizational & & & & 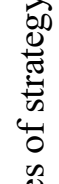 \\
\hline \multicolumn{2}{|c|}{ Characteristics of developers } & $\begin{array}{l}\text { Human } \\
\text { resource }\end{array}$ & & & $\frac{0}{\frac{\pi}{\pi}}$ \\
\hline \multicolumn{4}{|c|}{$\begin{array}{l}\text { Information systems, assessment and control, communications, } \\
\text { resource allocation, rewards and incentives }\end{array}$} & Process & \\
\hline
\end{tabular}

In another basic and conceptualized research study, Hosseini and his colleagues identified, extracted and presented a new conceptualization of success in strategic implementation. This model which has been extracted based on the grounded theory approach, consists of six sections that lead to success in strategic implementation. These sections or big factors are including: internal organizational factors, establishment of context, active senior management, organizational accompaniment, relative stability and finally successful implementation or execution [9]. Fig. 3 shows this basic and conceptualized model. 


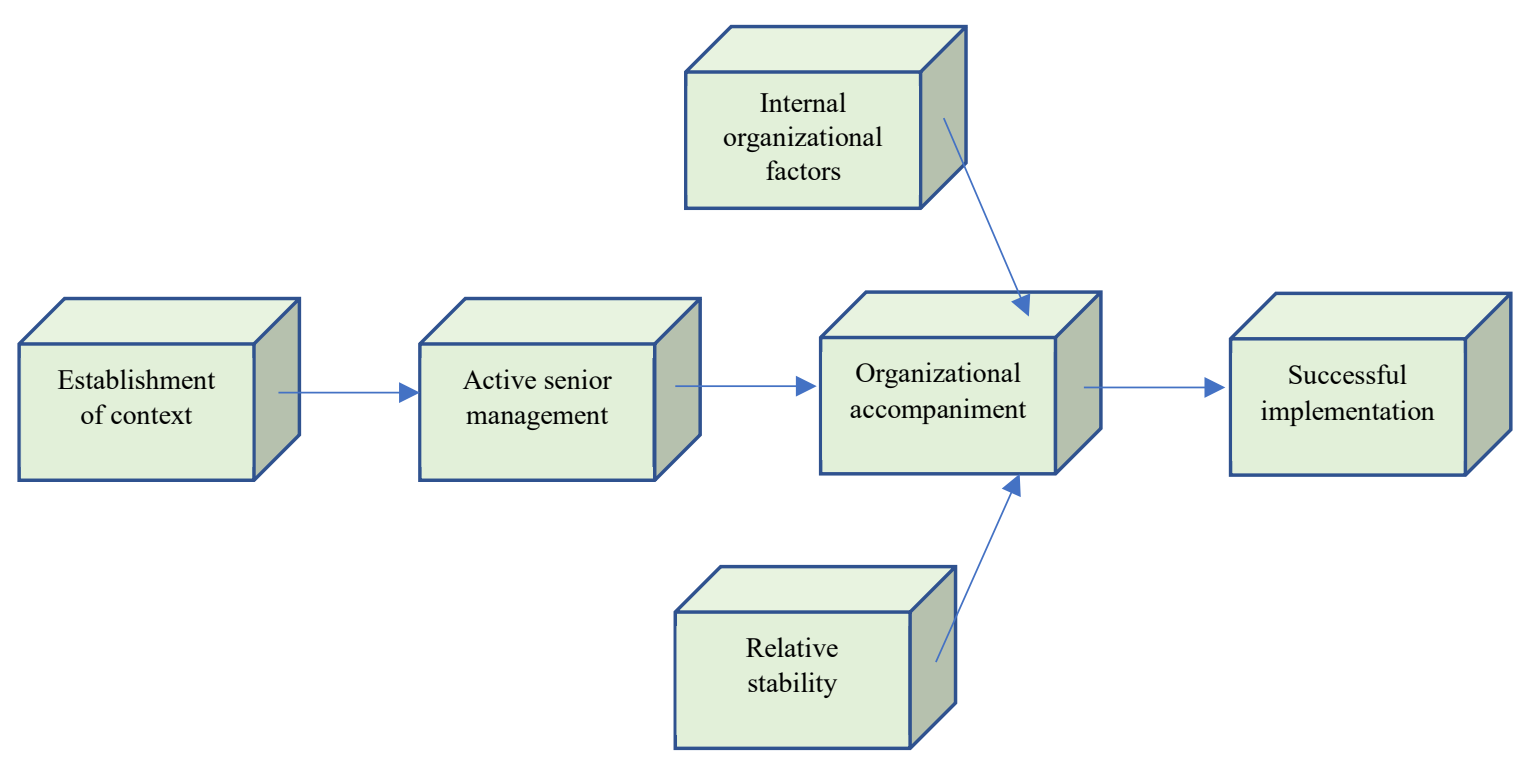

Figure 3. Conceptualized Model for Successful Strategy Implementation (adapted from [9])

\section{Research Design and Framework}

The main purpose of this research is to develop a conceptual framework to operationalize the strategies and strategic plans and, in this way, macro concepts and plans will become operationally measurable programs and can be measured quantitatively. In this case, organizational success will be achieved based on strategic implementation or execution. This research using qualitative approach and based on both detailed literature review and interview with experts of the filed tried to present a framework which help managers to execute their strategic plans in a convenient way. Fig. 4 shows the proposed steps and process to formation, selection, prioritize and operationalize the organizational strategies. 


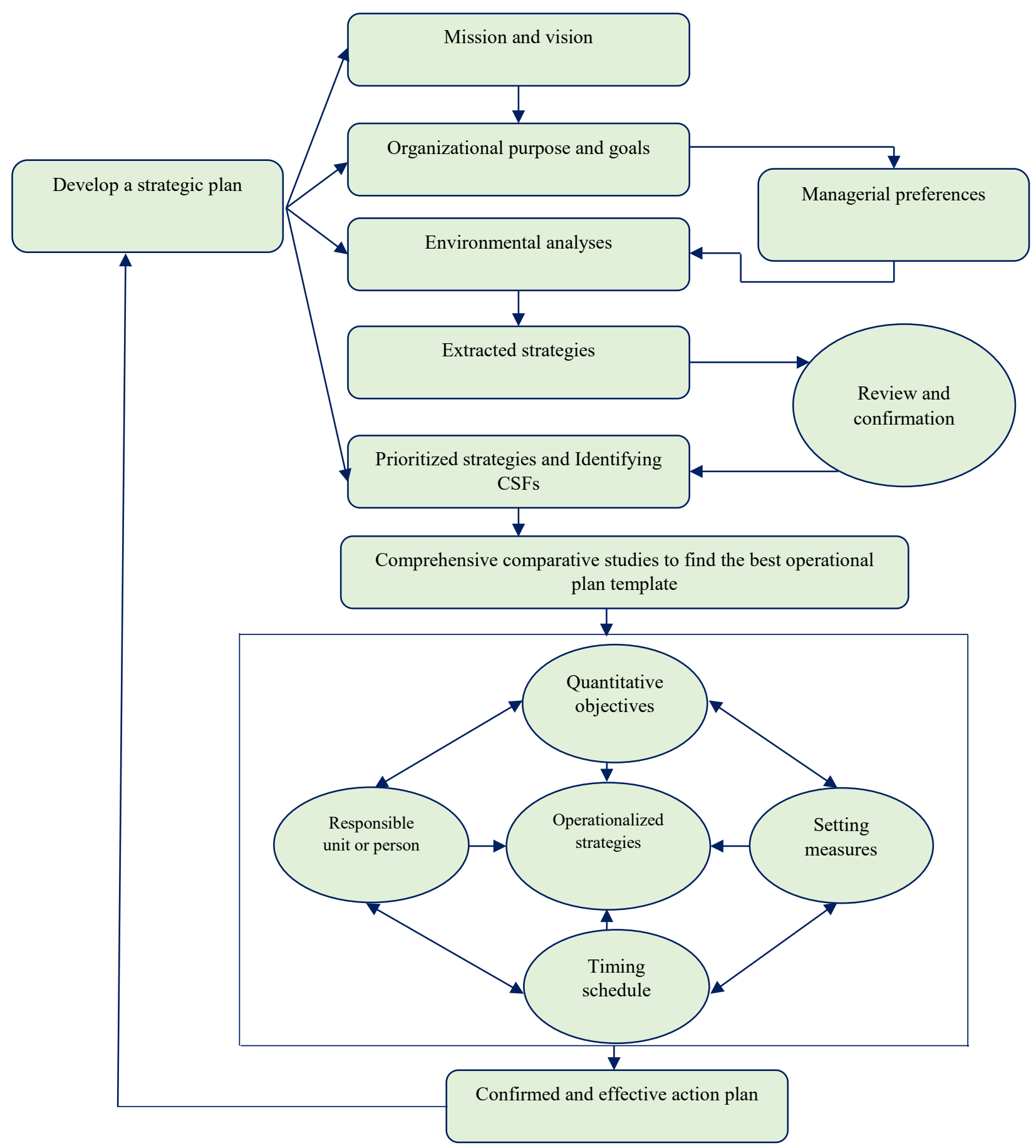

Figure 4. The proposed research conceptual framework

Also, the following worksheet displays details and different parts of the action plan. This worksheet differs from organization to organization and depends on the organization under review. In order to achieve this, a detailed comparative study is required to find the best operational program template. Here are the most important items for a plan action in the form of the following worksheet.

Table 3. The worksheet template for achieving an effective action plan for the organization

\begin{tabular}{|c|c|c|c|c|c|c|c|c|}
\hline \multicolumn{9}{|c|}{ 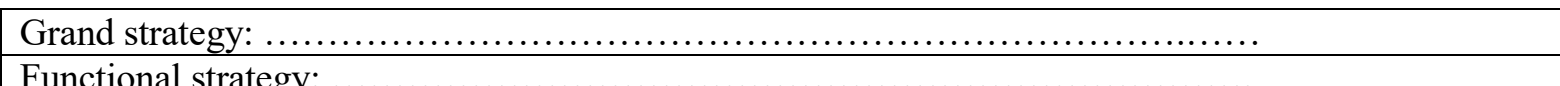 } \\
\hline \multicolumn{9}{|c|}{ 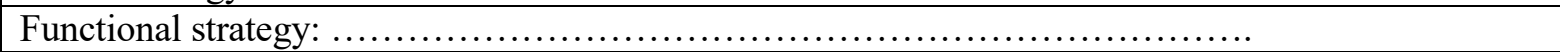 } \\
\hline No. & CSFs & $\begin{array}{c}\text { Quantitative } \\
\text { objectives }\end{array}$ & $\begin{array}{c}\text { Performance } \\
\text { measures }\end{array}$ & activities & $\begin{array}{l}\text { Time perioc } \\
\text { (year/month }\end{array}$ & Budget & $\begin{array}{l}\text { Responsible } \\
\text { unit }\end{array}$ & $\begin{array}{c}\text { Collaborate } \\
\text { units }\end{array}$ \\
\hline & & & & & & & & \\
\hline & & & & & & & & \\
\hline & & & & & & & & \\
\hline
\end{tabular}




\section{Data Analysis}

After extracting and presenting the conceptual framework of the research, in order to test and evaluate the research model, the necessary data are collected and analyzed. This section tells us what the appropriateness of the extracted framework in this research is. For this research, a model is presented that has dimensions and components. With the data obtained, the aim is to examine the applicability of each of them for the presence in the model and implementation of the strategy subsequently. For this purpose, the required data was collected through a questionnaire of a survey from research experts including experts in the field of study, scholars and practitioners. It has been asked 85 experts that each dimensions of the proposed research model are proportionate and accurate to be present in the final model of research. Are these dimensions precisely a good explanation for implementing strategy as a key stage of strategic management especially in the mission-based organizations.

The result of the data analysis at this stage is presented in two parts, in Tables 4 and 5 respectively. As can be seen, the results show that all dimensions of the research model have a significant coefficient of less than 5\% (Sig < 0.05). Also, all calculated averages for all dimensions of the research model are higher than the average of 3 (Means $>3,3=$ Test value). This means that according to the data collected and analyzed, all dimensions identified in this research for the proposed model are significant and remain in the final model. Accordingly, this model has the ability to track the implementation of the strategy in the organizations under this investigation.

Table 4. The One-Sample Statistics for the analysis of research framework

\begin{tabular}{|l|c|c|c|c|}
\hline \multicolumn{1}{|c|}{ Dimensions of the research conceptual framework } & $\mathrm{N}$ & Mean & $\begin{array}{c}\text { Std. } \\
\text { Deviatio } \\
\mathrm{n}\end{array}$ & $\begin{array}{c}\text { Std. } \\
\text { Error } \\
\text { Mean }\end{array}$ \\
\hline Develop a strategic plan & 85 & 4.6300 & .69680 & .04927 \\
\hline Mission and vision & 85 & 3.9000 & .66499 & .04702 \\
\hline Prioritized strategies and Identifying CSFs & 85 & 4.0500 & .66310 & .04689 \\
\hline Managerial preferences & 85 & 4.0750 & .72941 & .05158 \\
\hline Extracted strategies & 85 & 4.3650 & .70303 & .04971 \\
\hline Environmental analyses & 85 & 4.2400 & .78452 & .05547 \\
\hline Organizational purpose and goals & 85 & 3.8550 & .80449 & .05689 \\
\hline Review and confirmation & 85 & 3.8150 & .94618 & .06690 \\
\hline Comprehensive comparative studies & 85 & 4.1900 & .70454 & .04982 \\
\hline Operationalized strategies & 85 & 4.1700 & .77725 & .05496 \\
\hline Setting measures & 85 & 3.8200 & .61603 & .04356 \\
\hline Responsible unit or person & 85 & 3.8050 & .57325 & .04054 \\
\hline Quantitative objectives & 85 & 3.9000 & .67993 & .04808 \\
\hline Timing schedule & 85 & 3.6950 & .70317 & .04972 \\
\hline Confirmed and effective action plan & 85 & 4.0450 & .59561 & .04212 \\
\hline
\end{tabular}

Table 5. The One-Sample Test for the analysis of research framework

\begin{tabular}{|c|c|c|c|c|c|c|}
\hline \multirow{3}{*}{$\begin{array}{c}\text { Dimensions of the research conceptual } \\
\text { framework }\end{array}$} & \multicolumn{6}{|c|}{ Test Value $=3$} \\
\hline & \multirow[t]{2}{*}{$\mathrm{t}$} & \multirow[t]{2}{*}{$\mathrm{df}$} & \multirow{2}{*}{ 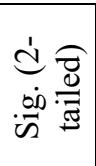 } & \multirow{2}{*}{ 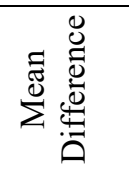 } & \multicolumn{2}{|c|}{$\begin{array}{l}95 \% \text { Confidence } \\
\text { Interval of the } \\
\text { Difference }\end{array}$} \\
\hline & & & & & Lower & Upper \\
\hline Develop a strategic plan & 33.082 & 84 & .000 & 1.63000 & 1.5328 & 1.7272 \\
\hline Mission and vision & 19.140 & 84 & .000 & .90000 & .8073 & .9927 \\
\hline Prioritized strategies and Identifying CSFs & 22.394 & 84 & .000 & 1.05000 & 9575 & 1.1425 \\
\hline Managerial preferences & 20.843 & 84 & .000 & 1.07500 & .9733 & 1.1767 \\
\hline Extracted strategies & 27.458 & 84 & .000 & 1.36500 & 1.2670 & 1.4630 \\
\hline Environmental analys & 22.353 & 84 & .000 & 1.24000 & 1.1306 & 1.3494 \\
\hline Organizational purpose & 15.030 & 84 & .000 & .85500 & .7428 & .9672 \\
\hline Review and confirmation & 12.181 & 84 & .000 & .81500 & .6831 & .9469 \\
\hline Comprehensive comparative studies & 23.887 & 84 & .000 & 1.19000 & 1.0918 & 1.2882 \\
\hline Operationalized strategies & 21.288 & 84 & .000 & 1.17000 & 1.0616 & 1.2784 \\
\hline Setting measures & 18.825 & 84 & .000 & .82000 & .7341 & .9059 \\
\hline
\end{tabular}




\begin{tabular}{|c|c|c|c|c|c|c|}
\hline \multirow{3}{*}{$\begin{array}{l}\text { Dimensions of the research conceptual } \\
\text { framework }\end{array}$} & \multicolumn{6}{|c|}{ Test Value $=3$} \\
\hline & \multirow[t]{2}{*}{$\mathrm{t}$} & \multirow[t]{2}{*}{ df } & \multirow{2}{*}{ 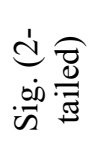 } & \multirow{2}{*}{ 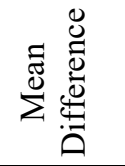 } & \multicolumn{2}{|c|}{$\begin{array}{l}95 \% \text { Confidence } \\
\text { Interval of the } \\
\text { Difference }\end{array}$} \\
\hline & & & & & Lower & Upper \\
\hline Responsible unit or persc & 19.859 & 84 & .000 & .80500 & .7251 & .8849 \\
\hline Quantitat & 18. & 84 & .000 & .90000 & .8052 & .9948 \\
\hline Timing sch & 13.978 & 84 & .000 & .69500 & .5970 & .7930 \\
\hline Confirmed and effective action plan & 24.813 & 84 & .000 & 1.04500 & .9619 & 1.1281 \\
\hline
\end{tabular}

After performing the previous statistical analysis and presenting its results, in order to see the dimensions of the research model and a better understanding, a detailed bar chart is drawn up. For this purpose, previous test data have been used. In this way, using the calculated mean for each dimension of the research model, the desired graph is plotted and presented.

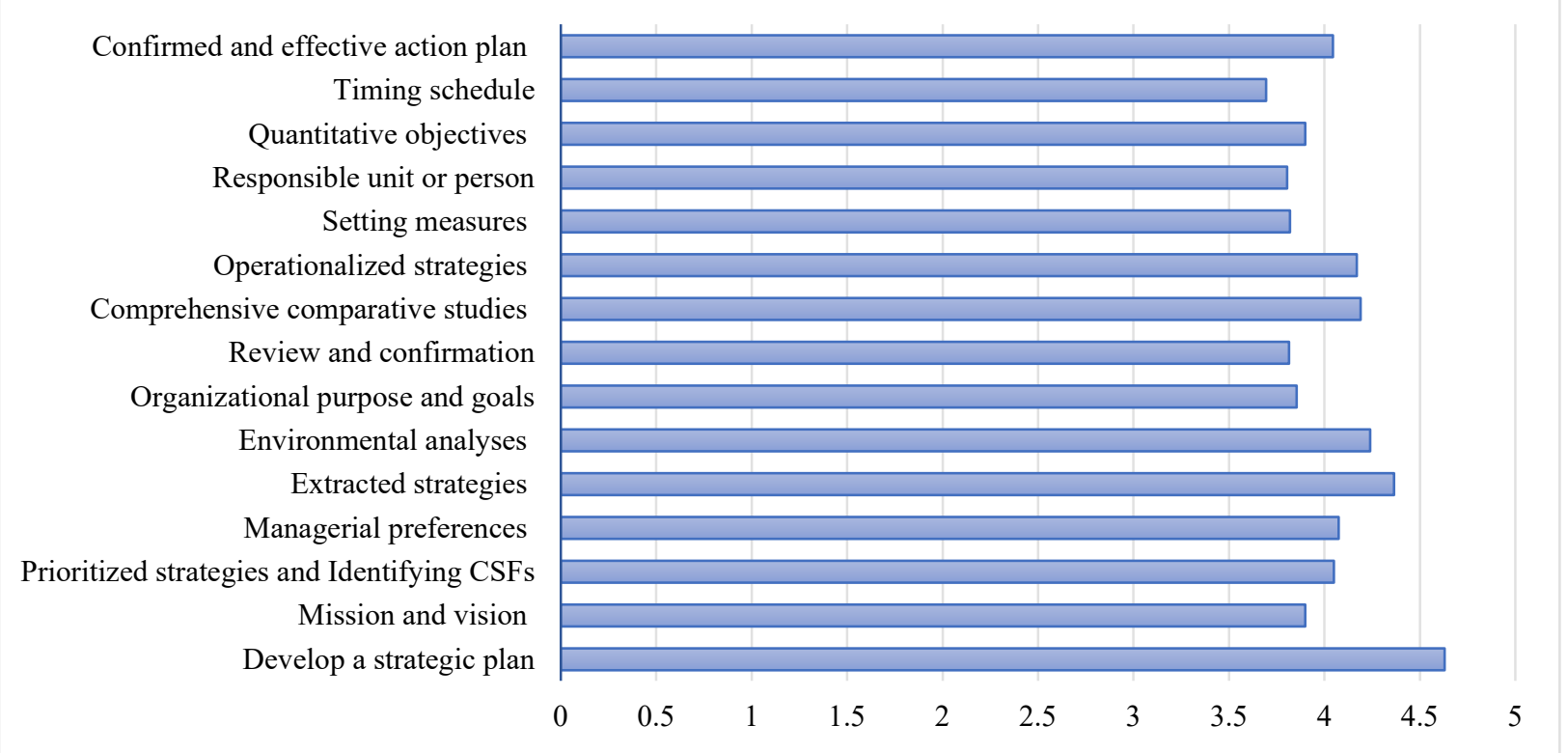

Figure 5. The result of data analysis for appropriateness of model's dimensions

\section{Concluding Remarks}

Because in today's dynamic environment we need a comprehensive, long-term approach to organizational issues, strategic management is the best option for corporate executives and policymakers. The language of strategy is largely abstract and far from running. Therefore, it is necessary to translate and analyze in a simple and operational language. Organizations are always looking for ways to turn their grand strategies into a feasible operational or action plan and align the organization's human resources with it. In this study, we tried to extract and suggest a conceptual framework and operational model of strategies and their associated implementation action plans for organizations with focus on the mission-based organizations.

It is emphasized that in order to achieve the pattern and template of converting the strategic plan into an operational program, there is a need for a detailed comparative study of similar organizations in that industry; to get the best pattern and template for this purpose. Also, the effectiveness of the extracted operational plan is highly dependent on the commitment of the organization's top management and its organizational human resources to implement its action plan and programs with commitment and responsibility. In this research, after extracting the conceptual framework of the research and its fundamental dimensions for strategic implementation, using the views of the experts and stakeholders of the study area, the necessary data were collected and analyzed. The results showed that this model is suitable for application in organizations for implementing step-by-step strategic implementation. The proposed stepwise approach in this research have many uses for managers who seek to real and practical implement their organizational 
strategies. In addition, the results and outcomes of this research are also useful for future researchers to use their research in their organizations and to carry out more comprehensive research in the area of expertise.

\section{Conflict of Interest}

The authors declare that there is no conflict of interest.

\section{References}

[1] M.K. Allio, Strategic dashboards: designing and deploying them to improve implementation, Strategy \& Leadership. 40(5) (2012) 24-31.

[2] M.T. Amini, S. Khabbaz, Strategy formulation using the comprehensive framework for strategic compilation - case study: Sahand Khodro Tabriz Co, Journal of Business Management. 1(2) (2009) 17-32.

[3] S.M. Arabi, Strategic Planning Manual, Cultural Research Bureau, Tehran, Iran, 2006.

[4] F.R. David, Fundamentals of strategic management, Macmillan Pub Co, 1986.

[5] F.R. David, How companies define their mission, Long Range Planning. 22(1) (1989) 90-97.

[6] F.R. David, Strategic management: Concepts and cases, Peaeson/Prentice Hall, 2011.

[7] D. Dmitrieva, A. Ilinova, A. Kraslawski, Strategic management of the potash industry in Russia, Resources Policy. 52 (2017) 81-89.

[8] P. Ghemawat, Competition and business strategy in historical perspective, Business History Review. 76(1) (2002) 37-74.

[9] S.F. Hoseini et al., Presentation the model of successful implementation strategy in Iranian automobile companies, Iranian Quarterly of Management Sciences. 9(36) (2014) 1-24.

[10] L.G. Hrebiniak, Making strategy work: Leading effective execution and change, FT Press, 2013.

[11] C. Jooste, B. Fourie, The role of strategic leadership in effective strategy implementation: Perceptions of South African strategic leaders, Southern African Business Review. 13(3) (2009).

[12] R.S. Kaplan, D.P. Norton, Strategy maps: Converting intangible assets into tangible outcomes, Harvard Business Press, 2004.

[13] R.S. Kaplan, D.P. Norton, The office of strategy management, Strategic Finance. 87(4) (2005) 8-30.

[14] S.X. Liu, C. de Bont, Barriers to strategic design: a perspective from China, She Ji: The Journal of Design, Economics, and Innovation. 3(2) (2017) 133-145.

[15] N. Mazloumi, A. Motavali, A model for the implementation of strategic plans, Management Studies Quarterly. 22(67) (2012) 19-45.

[16] H. Mintzberg, J. Lample, Reflection on the strategy process strategic thinking for the next economy, Sossey-Bass, 2001. Available at: http://sloanreview. mit.edu/article/reflecting-onthe-strategy-process.

[17] M.M. Mondragón-Ixtlahuac, J.C. Cortés-Martínez, D.J. Delgado-Hernández, A strategic planning model for the passenger rail implementation process: The case of Mexico, Transport Policy. 55 (2017) 29-37.

[18] W. Mulcaster, Three strategic frameworks, Business Strategy Series. 10(1) (2008) 68-75. 
[19] R. Nag, D.C. Hambrick, M.J. Chen, What is strategic management, really? Inductive derivation of a consensus definition of the field, Strategic Management Journal. 28(9) (2007) 935-955.

[20] F. Nickols, Strategy, strategic management, strategic planning and strategic thinking, Distance Consulting LLC, 2011, pp. 1-8.

[21] N. Pröllochs, S. Feuerriegel, Business analytics for strategic management: Identifying and assessing corporate challenges via topic modelling, Information \& Management. (2018).

[22] M.G. Pryor et al., Strategic implementation as a core competency: the 5P's model, Journal of Management Research. 7(1) (2007) 3-15.

[23] M. Safari, A conceptual model to explain strategic alignment in the financial services based on Balanced Scorecard, International Letters of Social and Humanistic Sciences. 43 (2014) 98-108.

[24] N. Shahlaee, Strategic management in armed forces, Quarterly Military Management. 28 (2007) 101-140.

[25] A. Toolsee, Successful criteria for implementing strategies within the banking industry, Doctoral dissertation, 2012.

[26] A.D. Chandler, Strategy and Structure, Massachusetts Institute of Technology Cambridge, 1962. 